\title{
Numerical Modeling and Simulation of Fatigue Crack Growth Rate Due to Cyclic Loading on Doubler Structure Fuselage Skin Station Number 360-380 Stringer 61-71 Boeing 737-900 Extended Range Aircraft
}

\author{
Lado Rislya Prakasa ${ }^{1}$, Djarot Wahju Santoso \\ 1,2Department of Aerospace Engineering, Adisutjipto Institute of Technology, Indonesia \\ Email: ladoprakasa@gmail.com
}

Received: September 04, 2021 ; Accepted : September 24, 2021 ; Published : November 01, 2021

\begin{abstract}
ABSTRCT
In order to determine the strength of the doubler structure in resisting failure due to cracks caused by cyclic loading, a specific analysis excluded from Structural Repair Manual (SRM) is necessary. The cyclic loading can reduce the strength of the skin doubler in a gradual manner (i.e. fatigue) until reaching fracture. This research will analyze the crack growth rate and the number of loading cycles required to generate a crack with a certain length (i.e. fatigue cycle) in the doubler fuselage skin structure of the Boeing 737-900 Extended Range aircraft with a station number of 360-380 between $6 L-7 L$ stringers at certain crack lengths and simulated flight altitudes. The analysis was carried out by using a numerical approach employing Modified Virtual Crack Closure Integral (MVCCI) method to obtain the Stress Intensity Factor (SIF) value through a finite-element based software. Through the values obtained, it can be seen that the value of the crack growth rate and fatigue cycle is directly proportional to the certain crack lengths and simulated flight altitudes. The lowest crack growth rate was produced in the result of doubler structure with a crack length of 8,5 mm and a flight altitude of 5000 feet, which was $2,964 \times 10^{-15} \mathrm{~mm} / \mathrm{cycle}$, and the highest value of $5,471 \times 10^{-12} \mathrm{~mm} / \mathrm{cycle}$ was found for doubler structure with a crack length of $51 \mathrm{~mm}$ and flight altitude of 40000 feet. Meanwhile, the lowest number of fatigue cycle value was obtained in the result of doubler structure with a crack length of $8,5 \mathrm{~mm}$ and a flight altitude of 40000 feet, which was $2,540 \times 10^{13}$ cycle, and the highest value (i.e. $5,470 \times 10^{15}$ cycle) was calculated in the case of doubler structure with a crack length of $51 \mathrm{~mm}$ and a flight altitude of 5000 feet.
\end{abstract}

Keywords: Crack growth rate, Doubler structure, Fatigue cycle

\begin{abstract}
ABSTRAK
Untuk mengetahui kekuatan struktur doubler dalam menahan terjadinya kegagalan akibat retakan yang disebabkan oleh cyclic loading, diperlukan suatu analisis tersendiri yang tidak terdapat pada panduan Structural Repair Manual (SRM). Cyclic loading dapat mengurangi kekuatan skin doubler secara bertahap (fatigue) hingga mencapai kegagalan (fracture). Pada penelitian ini akan dilakukan analisis crack growth rate dan jumlah siklus pembebanan yang dibutuhkan untuk memunculkan retakan dengan panjang tertentu (fatigue cycle) terhadap struktur doubler fuselage skin pesawat Boeing 737-900 Extended Range dengan station number 360-380 di antara stringer 6L-7L pada setiap panjang retakan dan ketinggian terbang simulasi. Analisis dilakukan menggunakan pendekatan numerik dengan metode Modified Virtual Crack Closure Integral (MVCCI) untuk mendapatkan nilai Stress Intensity Factor (SIF) melalui software berbasis metode elemen hingga. Melalui nilai yang diperoleh dapat diketahui bahwa nilai crack growth rate dan fatigue cycle berbanding lurus terhadap variasi panjang retakan dan ketinggian terbang simulasi yang diberikan. Nilai crack growth rate paling rendah terjadi pada struktur doubler dengan panjang retakan $8,5 \mathrm{~mm}$ dan kondisi terbang 5000 feet yaitu sebesar $2,964 \times 10^{-15} \mathrm{~mm} /$ cycle, dan nilai tertinggi sebesar 5,471 $\times 10^{-12} \mathrm{~mm} /$ cycle terjadi pada struktur doubler dengan panjang retakan $51 \mathrm{~mm}$ dan kondisi terbang 40000 feet. Sedangkan, nilai fatigue cycle paling rendah terjadi pada struktur doubler dengan panjang retakan $8,5 \mathrm{~mm}$ dan kondisi terbang 40000 feet yaitu sebesar $2,540 \times 10^{13}$ cycle, dan nilai tertinggi sebesar $5,470 \times 10^{15}$ cycle terjadi pada struktur doubler dengan panjang retakan $51 \mathrm{~mm}$ dan kondisi terbang 5000 feet.
\end{abstract}

Kata Kunci : Crack growth rate, Fatigue cycle, Struktur doubler

\section{PENGANTAR}

Pesawat Boeing 737-900 Extended Range senantiasa dilakukan inspeksi dan pemeliharaan sesuai dengan regulasi global oleh operator, agar pesawat terhindar dari damage dan tersertifikasi laik terbang (airworthy). Salah satu jenis kegiatan pemeliharaan yang dapat dilakukan terhadap pesawat Boeing 737-900 Extended Range adalah perlakuan repair pada fuselage skin dengan station number 360-380 di antara stringer 6L-7L. Repair pada bagian tersebut dilakukan karena ditemukan damage yang bisa berupa retakan atau kerusakan jenis lain. Boeing selaku pihak manufaktur secara resmi mengeluarkan dokumen Structural 
Repair Manual (SRM) yang dapat digunakan sebagai panduan bagi operator untuk menangani damage yang terjadi pada struktur rangka (frame) pesawat Boeing 737-900 Extended Range. Panduan bagi operator untuk menangani kasus damage yang terjadi pada fuselage skin dengan station number 360-380 di antara stringer 6L-7L adalah Structural Repair Manual (SRM) Boeing 737-900 Extended Range part 53 subjek 53-00-01 bagian repair 3. Berdasarkan Structural Repair Manual (SRM), damage yang terjadi pada fuselage skin dengan lokasi tersebut harus diberi pelakuan perbaikan (repair) berupa pemasangan skin doubler atau lembaran pelat baru yang berfungsi untuk menutup potongan skin bekas damage.

Telah banyak dilakukan penelitian terkait dengan nilai kekuatan struktur repair doubler pada fuselage skin, beberapa diantaranya seperti yang ditampilkan pada referensi [1], [2], dan [3]. Beberapa penelitian tersebut mengkaji kekuatan struktur repair doubler yang diaplikasikan pada pesawat komersial akibat dikenai pembebanan statik, dan pemasangan struktur skin doubler dinyatakan aman terhadap pembebanan statik jika mengikuti arahan pada Structural Repair Manual (SRM). Akan tetapi, kekuatan dari skin doubler untuk menahan terjadinya kegagalan akibat retakan dengan panjang tertentu yang disebabkan oleh cyclic loading belum diketahui secara pasti dalam panduan Structural Repair Manual (SRM). Pengulangan secara terus menerus dari pembebanan yang berfluktuasi di bawah nilai yield strength material (cyclic loading) terhadap skin doubler dapat mengurangi kekuatan material secara bertahap (fatigue) hingga material tersebut gagal (fracture). Selain itu, kegagalan pada kasus ini tidak didahului oleh deformasi plastis yang besar, sehingga lebih sulit untuk mendeteksi awal kegagalan pada struktur material daripada kegagalan yang diakibatkan oleh beban statik.

Kekuatan skin doubler untuk menahan terjadinya kegagalan akibat retakan dengan panjang tertentu yang disebabkan oleh cyclic loading ini penting untuk diketahui, agar operator dapat mengetahui kapan struktur tersebut lelah yang nantinya dapat menginisiasi terjadinya crack akibat pembebanan berulang (cyclic loading). Nilai pembebanan berulang dalam kasus ini didapat dari perbedaan tekanan di dalam dan di luar kabin pada ketinggian terbang simulasi. Inisiasi retakan di bawah nilai pembebanan yang sama dapat memunculkan rambat retak hingga ke fracture pada struktur uji, jika nilai faktor konsentrasi tegangan di ujung retakan tidak segera dihilangkan atau paling tidak dikurangi.

Untuk itu, pada penelitian ini akan dilakukan analisis crack growth rate dan jumlah siklus pembebanan yang dibutuhkan untuk memunculkan retakan dengan panjang tertentu (fatigue cycle) terhadap struktur doubler fuselage skin pesawat Boeing 737-900 Extended Range dengan station number 360-380 di antara stringer $6 \mathrm{~L}-7 \mathrm{~L}$ pada setiap panjang retakan dan ketinggian terbang simulasi. Panjang retakan simulasi adalah panjang retakan awal sebesar $8,5 \mathrm{~mm}$ dengan increment rambatan retak sebesar 8,5 mm hingga panjang retakan akhir sebesar $51 \mathrm{~mm}$. Ketinggian terbang simulasi adalah ketinggian terbang awal sebesar 5000 feet dengan increament ketinggian terbang sebesar 5000 feet hingga ketinggian terbang akhir sebesar 40000 feet.

\section{METODE PENELITIAN}

\subsection{Pengumpulan Data}

Pengumpulan data dilakukan melalui beberapa metode seperti berikut:

a. Studi pustaka, melalui metode ini penulis mengumpulkan materi atau data yang berasal dari sumber yang dapat dipertanggungjawabkan kevalidannya. Sumber tersebut adalah buku panduan perawatan struktur pesawat Boeing 737-900 Extended Range yang dikeluarkan oleh pabrikan pesawat, buku teori rujukan, jurnal peneliti sebelumya yang terkait dengan penelitian penulis, dan artikel ilmiah yang berasal dari situs internet untuk menambah wawasan ilmiah penulis. Pada metode ini, penulis juga melakukan pendalaman tentang bagaimana mengoperasikan softwaresoftware untuk kebutuhan penelitian terutama software CATIA V5R21 dan SIMULIA ABAQUS. Selain itu, penulis juga melakukan pendalaman materi terkait dengan mekanika rambat retak dan siklus lelah material terhadap struktur doubler akibat dikenai pembebanan berulang. Adapun beberapa data yang didapatkan melalui metode ini adalah sebagai berikut:

1). Persamaan matematis untuk kebutuhan analisis mekanika retakan pada penelitian ini. Adapun beberapa persamaan matematis tersebut adalah seperti berikut:

$$
\begin{aligned}
& \Delta P=P_{\text {in }}-P_{\text {out }} \\
& \sigma_{h}=\frac{\Delta P \times w}{{ }^{t}} \\
& G_{c}=\frac{F_{n} \times \Delta u}{2 \times \Delta b \times t} \\
& K=\sqrt{G_{c} \times E} \\
& \left(\frac{d a}{d N}\right)_{i}=C \times(\Delta K)_{i}{ }^{m} \\
& \Delta a_{i}=a_{i}-a_{i-1}
\end{aligned}
$$


Numerical Modeling and Simulation of Fatigue Crack Growth Rate Due To Cyclic Loading on ...

$$
\begin{aligned}
& \Delta N_{i}=\frac{\Delta a_{i}}{\left(\frac{d a}{d N}\right)_{i}} \\
& N_{i}=\Delta N_{i}+N_{i-1} \\
& \Delta K=K-K_{o p} \\
& K_{o p}=K \times(0,5+0,4 \times R) \\
& R=\frac{\sigma_{\min }}{\sigma_{\max }} \\
& M_{c}=\left|\frac{H^{n}-H^{n-1}}{H^{n}}\right| \times 100 \%
\end{aligned}
$$

\begin{tabular}{|c|c|}
\hline$\sigma_{h}$ & $=$ Tegangan hoop $(\mathrm{Pa})$ \\
\hline$\Delta P$ & $=$ Perbedaan tekanan di dalam dan di luar kabin pesawat $(\mathrm{Pa})$ \\
\hline$w$ & $=$ Lebar fuselage skin doubler $(\mathrm{mm})$ \\
\hline$t$ & $=$ Tebal fuselage skin doubler $(\mathrm{mm})$ \\
\hline$P_{\text {out }}$ & $=$ Tekanan udara di luar kabin $(P a)$ \\
\hline$P_{\text {in }}$ & $=$ Tekanan udara di dalam kabin $(P a)$ \\
\hline$K$ & $=$ Faktor intensitas tegangan $(M P a \sqrt{m})$ \\
\hline$G_{c}$ & $=$ Strain energy release rate $\left(\frac{\mathrm{N}}{\mathrm{mm}}\right)$ \\
\hline$E$ & $=$ Modulus elastisitas material $(G P a)$ \\
\hline$F_{n}$ & $=$ Nilai gaya pada nodal di ujung retakan $(N)$ \\
\hline$\Delta u$ & $=$ Crack Opening Displacement $(\mathrm{mm})$ \\
\hline$\Delta b$ & $=$ Panjang tepi elemen di dekat ujung retakan $(\mathrm{mm})$ \\
\hline$t$ & $=$ Tebal material $(\mathrm{mm})$ \\
\hline i & $=$ Perhitungan ke $1,2,3 \ldots . .6$ \\
\hline $\mathrm{i}=1$ & $=a_{i}=8,5 \mathrm{~mm} ; a_{i-1}=0 \mathrm{~mm}$ \\
\hline $\mathrm{i}=2$ & $=a_{i}=17 \mathrm{~mm} ; a_{i-1}=8,5 \mathrm{~mm}$ \\
\hline $\mathrm{i}=3$ & $=a_{i}=25,5 \mathrm{~mm} ; a_{i-1}=17 \mathrm{~mm}$ \\
\hline $\mathrm{i}=4$ & $=a_{i}=34 \mathrm{~mm} ; a_{i-1}=25,5 \mathrm{~mm}$ \\
\hline $\mathrm{i}=5$ & $=a_{i}=42,5 \mathrm{~mm} ; a_{i-1}=34 \mathrm{~mm}$ \\
\hline$i=6$ & $=a_{i}=51 \mathrm{~mm} ; a_{i-1}=42,5 \mathrm{~mm}$ \\
\hline$N_{i}$ & $=$ Total fatigue cycle pada kondisi ke-i (siklus) \\
\hline$\Delta N_{i}$ & $=$ Crack propagation fatigue cycle pada kondisi ke-i (siklus) \\
\hline$N_{i-1}$ & $=$ Total fatigue cycle pada kondisi ke-i-1 (siklus) \\
\hline$\left(\frac{d a}{d N}\right)_{i}$ & $=$ Crack growth rate pada kondisi ke-i $(\mathrm{mm} /$ cycle $)$ \\
\hline$(\Delta K)_{i}$ & $=$ cyclic stress intensity factor pada kondisi ke-i $(M P a \sqrt{\mathrm{m}})$ \\
\hline$C$ dan $m$ & $=$ konstanta properti meterial \\
\hline$\Delta a_{i}$ & $=$ crack propagation length pada kondisi ke-i $(\mathrm{mm})$ \\
\hline$a_{i}$ & $=$ Panjang retakan pada kondisi ke-i $(\mathrm{mm})$ \\
\hline$a_{i-1}$ & $=$ Panjang retakan pada kondisi ke-i-1 $(\mathrm{mm})$ \\
\hline$R$ & $=$ Stress ratio \\
\hline$\sigma_{\min }$ & $=$ Minimum stress $(\mathrm{MPa})$ \\
\hline$\sigma_{\max }$ & $=$ Maximum stress $(\mathrm{MPa})$ \\
\hline$K_{o p}$ & $=$ Stress intensity factor opening $(M P a \sqrt{\mathrm{m}})$ \\
\hline & $=$ Mesh convergence $(\%)$ \\
\hline$H^{n-1}$ & $=$ Nilai gaya nodal di ujung retakan pada iterasi meshing $\mathrm{n}-1(\mathrm{~N})$ \\
\hline$H^{n}$ & $=$ Nilai gaya nodal di ujung retakan pada iterasi meshing $\mathrm{n}(\mathrm{N})$ \\
\hline
\end{tabular}

Keterangan:

2). Geometri dan material properti struktur doubler seperti yang ditampilkan pada sub bab 2.2.

b. Wawancara, melalui metode ini penulis berdiskusi dengan pihak yang lebih ahli dalam bidang terkait dengan materi judul penelitian penulis, terutama pada pembuatan fuselage skin doubler dan penentuan lokasi sumber atau referensi untuk penulis mendapatkan data yang valid. Selain untuk keperluan penelitian, hal ini juga bertujuan menambah wawasan ilmu penulis.

\subsection{Objek Penelitian}

Objek penelitian ini adalah struktur doubler pada fuselage skin dengan station number 360-380 di antara stringer 6L-7L pesawat Boeing 737-900 Extended Range. Data pada objek penelitian ini didapat dari Structural Repair Manual (SRM) Boeing 737-900 Extended Range part 53 subjek 53-00-01 bagian repair 3. Adapun gambar ilustrasi aplikasi struktur doubler pada fuselage stringer section ditampilkan pada gambar 1, 
dan gambar ilustrasi pemasangan struktur doubler pada fuselage skin ditampilkan pada gambar 2. Adapun ukuran geometri struktur fuselage skin doubler ditampilkan pada tabel 1.

Material yang digunakan pada struktur doubler adalah aluminium 2024-T3 dengan nilai properti material untuk kebutuhan analisis yang didapatkan dari referensi [4]. Nilai-nilai properti material tersebut ditampilkan pada tabel 2.

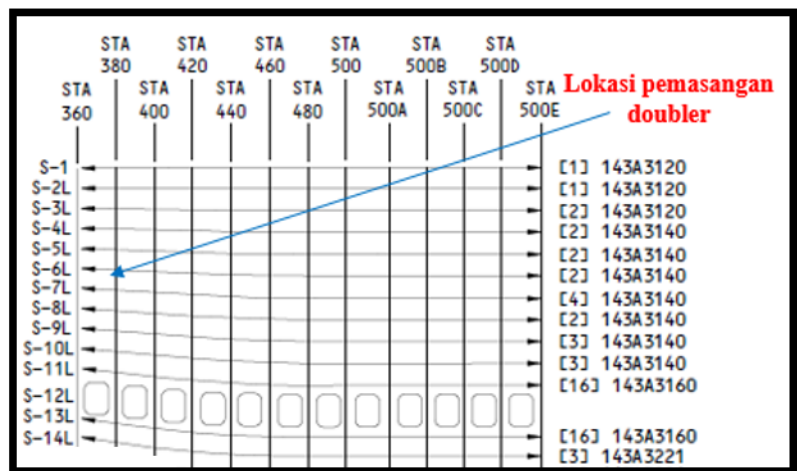

Gambar 1. Ilustrasi Lokasi Pemasangan Struktur Repair Doubler pada Fuselage Skin Pesawat Boeing 737 900 Extended Range [5]

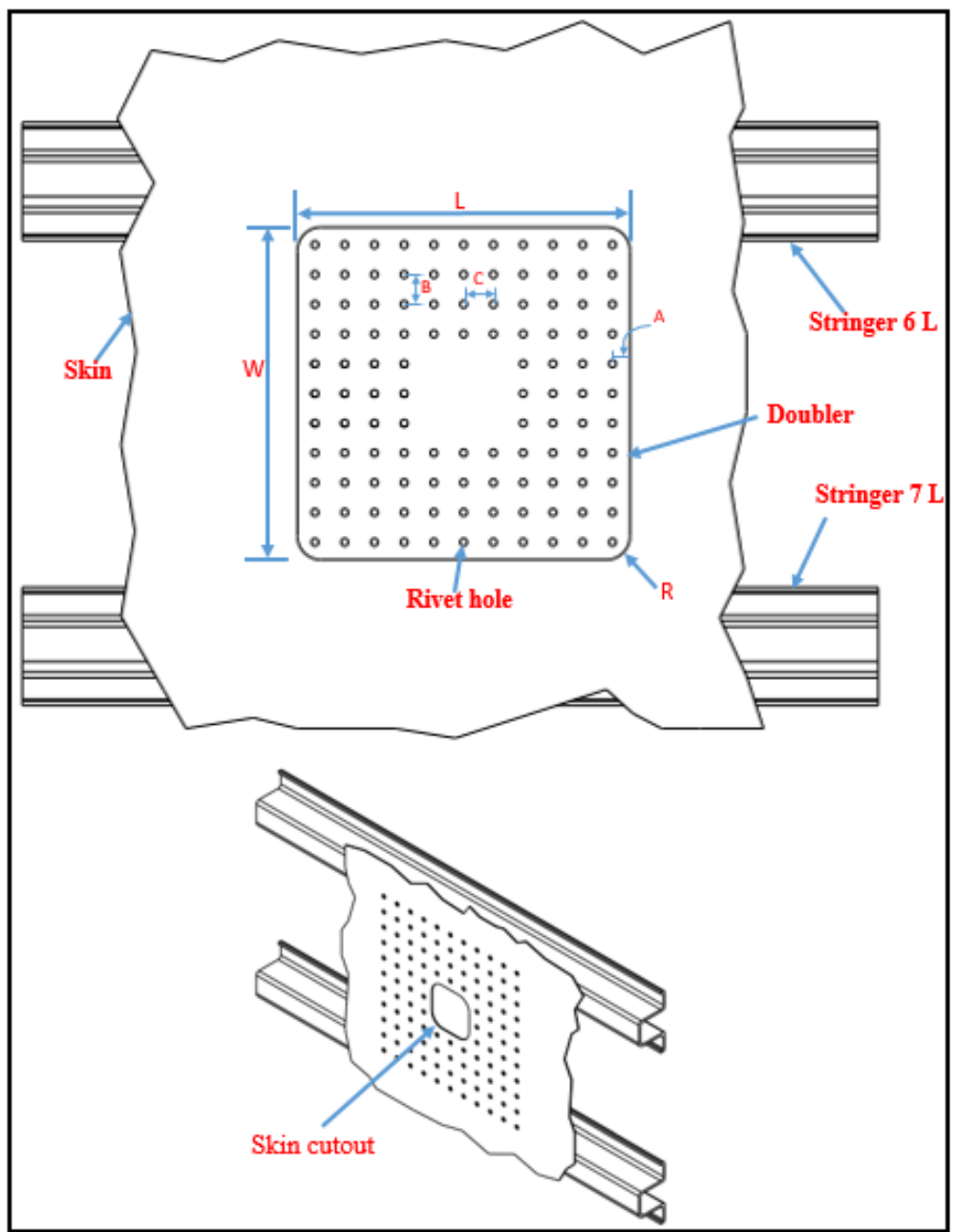

Gambar 2. Ilustrasi Pemasangan Struktur Doubler pada Fuselage Skin

Tabel 1. Ukuran Geometri Struktur Fuselage Skin Doubler

\begin{tabular}{ccc}
\hline No. & Geometri & Nilai \\
\hline 1. & A (edge distance doubler) & $9,398 \mathrm{~mm}$ \\
2. & B (tranverse pitch doubler) & $16,002 \mathrm{~mm}$ \\
3. & C (rivet pitch doubler) & $16,002 \mathrm{~mm}$ \\
\hline
\end{tabular}


Numerical Modeling and Simulation of Fatigue Crack Growth Rate Due To Cyclic Loading on ...

\begin{tabular}{ccc}
4. & $\mathrm{R}$ (radius doubler) & $12,7 \mathrm{~mm}$ \\
5. & Panjang skin cutout & $45,21 \mathrm{~mm}$ \\
6. & Lebar skin cutout & $45,21 \mathrm{~mm}$ \\
7. & Tebal skin & $1,016 \mathrm{~mm}$ \\
8. & Tebal doubler & $1,6002 \mathrm{~mm}$ \\
9. & L (Panjang doubler) & $178,82 \mathrm{~mm}$ \\
10. & W (Lebar doubler) & $178,82 \mathrm{~mm}$ \\
11. & Diameter rivet hole struktur doubler & $3,96875 \mathrm{~mm}$ \\
\hline
\end{tabular}

Tabel 2. Material Properti Aluminium 2024-T3

\begin{tabular}{ccc}
\hline No. & Geometri & Nilai \\
\hline 1. & Density & $2.77 \frac{\mathrm{g}}{\mathrm{cm}^{3}}$ \\
2. & Ultimate Tensile Strength & $483 \mathrm{MPa}$ \\
3. & Tensile Yield Strength & $362 \mathrm{MPa}$ \\
4. & Young's Modulus & $72 \mathrm{GPa}$ \\
5. & Poisson's Ratio & 0.33 \\
6. & Fracture Toughness & $72.37 \mathrm{MPa} \sqrt{\mathrm{m}}$ \\
7. & Crack growth rate axis intercept material constant $(\mathrm{C})$ & $5 \times 10^{-11}$ \\
8. & Paris regime slope material constant $(\mathrm{m})$ & 3 \\
\hline
\end{tabular}

Melalui data ukuran geometri struktur doubler yang ditampilkan pada tabel 1, dapat diketahui bahwa bentuk struktur doubler pada penelitian ini adalah simetris. Oleh karena itu, simulasi pembebanan pada penelitian ini dapat dilakukan dengan memodelkan struktur doubler menjadi setengah bagian agar proses simulasi dapat berlangsung lebih cepat dengan hasil yang sama seperti model utuh. Adapun pemodelan struktur doubler dengan bentuk setengah bagian ditampilkan pada gambar 3 .

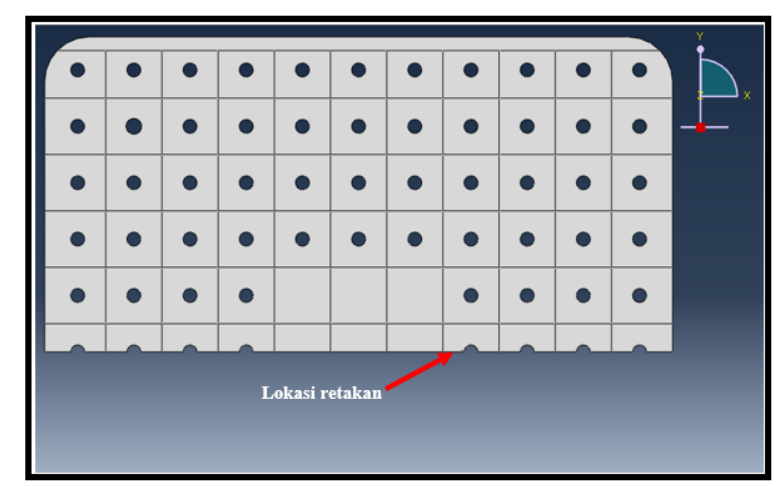

Gambar 3. Hasil Pemodelan Struktur Doubler dengan Bentuk Setengah Bagian Sebagai Objek Penelitian

\subsection{Simulasi Pembebanan dan Analisis Mekanika Retakan}

Simulasi pembebanan dilakukan menggunakan software SIMULIA ABAQUS. Adapun tahapan inti simulasi pembebanan dan analisis mekanika retakan adalah sebagai berikut:

a. Memodelkan struktur doubler sebagai elemen shell sesuai data geometri yang ditampilkan pada tabel 1 .

b. Mendefinisikan properti material struktur doubler untuk kebutuhan penelitian sesuai dengan jenis dan nilai properti seperti yang ditampilkan pada tabel 2.

c. Mendefinisikan alur tahapan simulasi (step) secara urut untuk dieksekusi oleh software SIMULIA ABAQUS. Alur eksekusi (step) pada penelitian ini terdiri dari:

1). Initial step, pada tahap ini ditetapkan kondisi batas awal sebelum dilakukan pembebanan dengan mengunci derajat kebebasan permukaan bagian bawah struktur doubler sebagai tumpuan tension load. Derajat kebebasan ini adalah gerakan translasi pada arah sumbu y, dan gerakan translasi pada arah sumbu z.

2). Loading step, pada tahap ini dilakukan pendefinisian jenis dan nilai pembebanan. Jenis pembebanan yang diterapkan pada struktur doubler adalah axial zero to tension cyclic loading dengan nilai pembebanan yang bersumber dari perbedaan tekanan di dalam dan di luar kabin pada ketinggian terbang simulasi. Perbedaan tekanan pada kabin akan mengenai luasan permukaan fuselage skin dan doubler sehingga mengakibatkan munculnya nilai tegangan hoop atau tegangan yang melingkar sepajang permukaan fuselage skin dan doubler. Adapun nilai tegangan hoop dapat diperoleh melalui persamaan matematis (2). 
d. Mendefiniskan nilai output atau hasil simulasi yang diinginkan dari proses simulasi pembebanan berupa nilai perpindahan nodal di daerah sekitar ujung retakan, dan nilai gaya pada nodal di ujung retakan dengan orientasi arah gaya yang searah dengan arah pembebanan

e. Melakukan proses meshing atau diskritasi pada model struktur doubler melalui panel meshing.

f. Melakukan proses eksekusi simulasi mekanika retakan pada setiap panjang retakan dan nilai pembebanan sesuai dengan urutan step yang didefinisikan sebelumnya.

g. Melakukan visualisasi hasil sesuai dengan nilai output atau hasil simulasi yang didefinisikan pada tahap sebelumnya.

h. Melakukan inspeksi konvergensi hasil (mesh convergence) terhadap variasi ukuran meshing di daerah sekitar ujung retakan melalui persamaan matematis (12). Uji konvergensi digunakan untuk validasi keakuratan hasil simulasi pembebaban. Nilai mesh convergence ditinjau pada hasil simulasi berupa nilai gaya nodal di ujung retakan yang diiterasi dengan jumlah elemen mesh tertentu. Proses iterasi hasil simulasi pada penelitian ini dilakukan sebanyak delapan kali percobaan, dan perlakuan meshing dianggap memberikan hasil simulasi yang baik jika nilai mesh convergence $<5 \%$. Jika nilai mesh convergence $>5 \%$, maka dilakukan proses meshing dan eksekusi simulasi ulang.

i. Setelah didapatkan nilai nodal force dan nodal displacement melalui simulasi pembebanan, maka tahap selanjutnya adalah analisis mekanika retakan struktur doubler berupa perhitungan nilai laju rambat retak dan fatigue cycle.

j. Analisis mekanika retakan pada setiap panjang retakan dan ketinggian terbang simulasi dilakukan pada struktur doubler yang telah dimodelkan dan dilakukan simulasi pembebanan. Melalui proses meshing dihasilkan nilai panjang tepi elemen di dekat ujung retakan $(\Delta b)$, dan melalui proses simulasi pembebanan dihasilkan nilai nodal force $\left(F_{n}\right)$ dan nodal displacement $(\Delta u)$. Nilai-nilai tersebut kemudian diolah menggunakan persamaan matematis (3) untuk mendapatkan nilai strain energy release rate $\left(G_{c}\right)$, dan melalui nilai strain energy release rate akan didapat nilai faktor intensitas tegangan (K) menggunakan persamaan matematis (4). Melalui nilai faktor intensitas tegangan didapatkan nilai faktor intensitas tegangan siklik $(\Delta K)$ menggunakan persamaan matematis (9). Nilai laju rambat retak $\left(\frac{d a}{d N}\right)$ dapat diperoleh menggunakan nilai faktor intensitas tegangan siklik melalui persamaan matematis (5), setelah itu nilai jumlah siklus pembebanan yang dibutuhkan untuk merambatkan retak (Crack propagation fatigue cycle) pada setiap kondisi panjang retakan simulasi dapat diperoleh menggunakan nilai laju rambat retak melalui persamaan matematis (7). Ketika panjang retakan tersebut terus merambat dengan nilai pertambahan panjang tertentu, jumlah total siklus pembebanan terhadap total panjang retakan pada kondisi saat itu dapat diketahui melalui persamaan matematis (8).

\section{HASIL DAN ANALISIS}

Adapun contoh gambar hasil simulasi pembebanan dengan output nilai nodal force pada panjang retakan 8,5 mm dan ketinggian terbang 5000 feet ditamplkan pada gambar 4 .

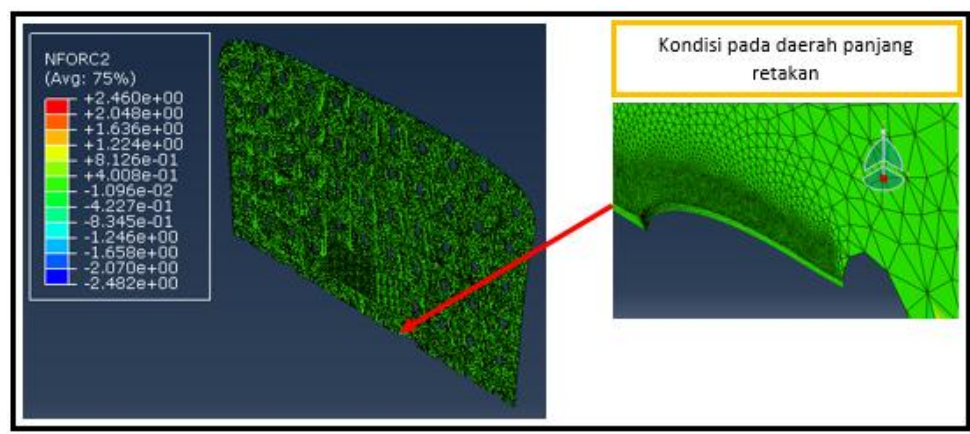

Gambar 4. Hasil Simulasi Pembebanan Struktur Doubler dengan Panjang Retakan 8,5 mm pada Ketinggian Terbang 5000 Feet

Adapun contoh perhitungan analisis mekanika retakan struktur doubler pada panjang retakan 8,5 mm dan ketinggian terbang 5000 feet adalah sebagai berikut:

$F_{n}$

$\Delta u$

$\Delta b$

Adapun nilai-nilai yang dibutuhkan untuk perhitungan adalah sebagai berikut.

$$
\begin{aligned}
& =0,268 \mathrm{~N} \\
& =0,000017 \mathrm{~mm} \\
& =0,017 \mathrm{~mm}
\end{aligned}
$$


Numerical Modeling and Simulation of Fatigue Crack Growth Rate Due To Cyclic Loading on ...

\begin{tabular}{|c|c|}
\hline$t$ & $=1,6002 \mathrm{~mm}$ \\
\hline$E$ & $=72 \mathrm{GPa}$ \\
\hline C & $=5 \times 10^{-11}$ \\
\hline$m$ & $=3$ \\
\hline$R$ & $=0$ \\
\hline$a_{i}$ & $=8,5 \mathrm{~mm}$ \\
\hline$a_{i-1}$ & $=0 \mathrm{~mm}$ \\
\hline$N_{i-1}$ & $=0$ \\
\hline
\end{tabular}

Melalui beberapa nilai di atas, nilai mekanika retakan struktur doubler pada panjang retakan 8,5 mm dan ketinggian terbang 5000 feet dapat diketahui dengan langkah pertama yang menghitung nilai faktor intensitas tegangan siklik seperti proses yang ditampilkan dibawah ini,

$G_{c}=\frac{F_{n} \Delta u}{2 \Delta b t}$

$G_{C}=\frac{(0,268 \mathrm{~N})(0,000017 \mathrm{~mm})}{2(0,017 \mathrm{~mm})(1,6002 \mathrm{~mm})}$

$G_{c}=0,000084 \frac{N}{\mathrm{~mm}}$

$K=\sqrt{G_{c} E}$

$K=\sqrt{\left(0,000084 \frac{N}{\mathrm{~mm}}\right)(72 G P a)}$

$K=0,078 M P a \sqrt{\mathrm{m}}$

$K_{o p}=K(0,5+0,4 R)$

$K_{o p}=0,078 \mathrm{MPa} \sqrt{\mathrm{m}}(0,5+0)$

$K_{o p}=0,039 M P a \sqrt{\mathrm{m}}$

$\Delta K=K-K_{o p}$

$\Delta K=0,078 M P a \sqrt{\mathrm{m}}-0,039 M P a \sqrt{\mathrm{m}}$

$\Delta K=0,039 M P a \sqrt{\mathrm{m}}$

Langkah berikutnya adalah menghitung nilai crack growth rate dengan proses seperti berikut,

$\left(\frac{d a}{d N}\right)_{i}=C(\Delta K)_{i}^{m}$

$\left(\frac{d a}{d N}\right)_{i}=5 \times 10^{-11}(0,039 \mathrm{MPa} \sqrt{\mathrm{m}})_{i}^{3}$

$\left(\frac{d a}{d N}\right)_{i}=2,964 \times 10^{-15} \mathrm{~mm} /$ cycle

Setelah nilai crack growth rate diketahui, selanjutnya dilakukan perhitungan nilai fatigue cycle dengan proses seperti berikut,

$\Delta a_{i}=a_{i}-a_{i-1}$

$\Delta a_{i}=8,5 \mathrm{~mm}-0$

$\Delta a_{i}=8,5 \mathrm{~mm}$

$\Delta N_{i}=\frac{\Delta a_{i}}{\left(\frac{d a}{d N}\right)_{i}}$

$\Delta N_{i}=\frac{8,5 \mathrm{~mm}}{2,964 \times 10^{-15} \mathrm{~mm} / \text { cycle }}$

$\Delta N_{i}=2,868 \times 10^{15}$ cycle

$N_{i}=\Delta N_{i}+N_{i-1}$

$N_{i}=2,868 \times 10^{15}$ cycle +0

$N_{i}=2,868 \times 10^{15}$ cycle

Analisis mekanika retakan struktur doubler dilakukan pada setiap panjang (a) dan kondisi terbang simulasi dengan proses perhitungan seperti yang dicontohkan pada contoh perhitungan analisis mekanika retakan pada panjang retakan $8,5 \mathrm{~mm}$ dan ketinggian terbang $5000 \mathrm{feet}$. Adapun hasil analisis mekanika retakan struktur doubler pada setiap panjang retakan dan ketinggian terbang simulasi adalah sebagai berkut:

a. Kondisi terbang 5000 feet

Tabel 3. Nilai Cyclic Stress Intensity Factor pada Kondisi Terbang 5000 Feet di Setiap Panjang

Retakan Simulasi

\begin{tabular}{cccccccc}
\hline No. & $\mathrm{a}(\mathrm{mm})$ & $\Delta b(\mathrm{~mm})$ & $\Delta u(\mathrm{~mm})$ & $F_{n}(N)$ & $G_{c}\left(\frac{N}{m m}\right)$ & $K(\operatorname{MPa} \sqrt{\mathrm{m}})$ & $\Delta K(\operatorname{MPa} \sqrt{\mathrm{m}})$ \\
\hline 1. & 8,5 & 0,017 & 0,000017 & 0,268 & 0,000084 & 0,078 & 0,039 \\
2. & 17 & 0,017 & 0,000023 & 0,364 & 0,000155 & 0,106 & 0,053 \\
\hline
\end{tabular}


Lado Rislya Prakasa, Djarot Wahju Santoso

$\begin{array}{lccccccc}\text { 3. } & 25,5 & 0,017 & 0,000028 & 0,445 & 0,000232 & 0,129 & 0,065 \\ \text { 4. } & 34 & 0,017 & 0,000033 & 0,522 & 0,000320 & 0,152 & 0,076 \\ \text { 5. } & 42,5 & 0,017 & 0,000038 & 0,600 & 0,000421 & 0,174 & 0,087 \\ \text { 6. } & 51 & 0,017 & 0,000043 & 0,681 & 0,000544 & 0,198 & 0,099\end{array}$

Tabel 4. Nilai Crack Growth Rate dan Fatigue Cycle pada Kondisi Terbang 5000 Feet di Setiap Panjang Retakan Simulasi

\begin{tabular}{ccccc}
\hline No. & Panjang Retakan $(\mathrm{mm})$ & $\frac{d a}{d N}(\mathrm{~mm} /$ cycle $)$ & $N_{i}($ cycle $)$ & $N_{f}($ cycle $)$ \\
\hline 1. & 8,5 & $2,964 \times 10^{-15}$ & $2,868 \times 10^{15}$ & $2,868 \times 10^{15}$ \\
2. & 17 & $7,389 \times 10^{-15}$ & $1,150 \times 10^{15}$ & $4,018 \times 10^{15}$ \\
3. & 25,5 & $1,352 \times 10^{-14}$ & $6,286 \times 10^{14}$ & $4,647 \times 10^{15}$ \\
4. & 34 & $2,180 \times 10^{-14}$ & $3,898 \times 10^{14}$ & $5,037 \times 10^{15}$ \\
5. & 42,5 & $3,301 \times 10^{-14}$ & $2,575 \times 10^{14}$ & $5,294 \times 10^{15}$ \\
6. & 51 & $4,845 \times 10^{-14}$ & $1,754 \times 10^{14}$ & $5,470 \times 10^{15}$ \\
\hline
\end{tabular}

b. Kondisi terbang 10000 feet

Tabel 5. Nilai Cyclic Stress Intensity Factor pada Kondisi Terbang 10000 Feet di Setiap Panjang

\begin{tabular}{cccccccc}
\multicolumn{7}{c}{ Retakan Simulasi } \\
\hline No. & $\mathrm{a}(\mathrm{mm})$ & $\Delta b(\mathrm{~mm})$ & $\Delta u(\mathrm{~mm})$ & $F_{n}(N)$ & $G_{c}\left(\frac{N}{\mathrm{~mm}}\right)$ & $K(\operatorname{MPa} \sqrt{\mathrm{m}})$ & $\Delta K(\operatorname{MPa} \sqrt{\mathrm{m}})$ \\
\hline 1. & 8,5 & 0,017 & 0,000031 & 0,492 & 0,000284 & 0,143 & 0,072 \\
2. & 17 & 0,017 & 0,000043 & 0,667 & 0,000522 & 0,194 & 0,097 \\
3. & 25,5 & 0,017 & 0,000052 & 0,816 & 0,000781 & 0,237 & 0,119 \\
4. & 34 & 0,017 & 0,000061 & 0,957 & 0,001074 & 0,278 & 0,139 \\
5. & 42,5 & 0,017 & 0,000070 & 1,099 & 0,001416 & 0,319 & 0,160 \\
6. & 51 & 0,017 & 0,000080 & 1,249 & 0,001829 & 0,363 & 0,181 \\
\hline
\end{tabular}

Tabel 6. Nilai Crack Growth Rate dan Fatigue Cycle pada Kondisi Terbang 10000 Feet di Setiap Panjang Retakan Simulasi

\begin{tabular}{ccccc}
\hline No. & Panjang Retakan $(\mathrm{mm})$ & $\frac{d a}{d N}(\mathrm{~mm} /$ cycle $)$ & $N_{i}($ cycle $)$ & $N_{f}($ cycle $)$ \\
\hline 1. & 8,5 & $1,827 \times 10^{-14}$ & $4,653 \times 10^{14}$ & $4,653 \times 10^{14}$ \\
2. & 17 & $4,553 \times 10^{-14}$ & $1,867 \times 10^{14}$ & $6,520 \times 10^{14}$ \\
3. & 25,5 & $8,332 \times 10^{-14}$ & $1,020 \times 10^{14}$ & $7,540 \times 10^{14}$ \\
4. & 34 & $1,344 \times 10^{-13}$ & $6,325 \times 10^{13}$ & $8,173 \times 10^{14}$ \\
5. & 42,5 & $2,034 \times 10^{-13}$ & $4,179 \times 10^{13}$ & $8,591 \times 10^{14}$ \\
6. & 51 & $2,986 \times 10^{-13}$ & $2,847 \times 10^{13}$ & $8,875 \times 10^{14}$ \\
\hline
\end{tabular}

c. Kondisi terbang 15000 feet

Tabel 7. Nilai Cyclic Stress Intensity Factor pada Kondisi Terbang 15000 Feet di Setiap Panjang Retakan Simulasi

\begin{tabular}{cccccccc}
\hline No & $\mathrm{a}(\mathrm{mm})$ & $\Delta b(\mathrm{~mm})$ & $\Delta u(\mathrm{~mm})$ & $F_{n}(N)$ & $G_{c}\left(\frac{N}{m m}\right)$ & $K(\operatorname{MPa} \sqrt{\mathrm{m}})$ & $\Delta K(\operatorname{MPa} \sqrt{\mathrm{m}})$ \\
\hline 1. & 8,5 & 0,017 & 0,000044 & 0,686 & 0,000552 & 0,199 & 0,100 \\
2. & 17 & 0,017 & 0,000059 & 0,930 & 0,001014 & 0,270 & 0,135 \\
3. & 25,5 & 0,017 & 0,000073 & 1,138 & 0,001517 & 0,331 & 0,165 \\
4. & 34 & 0,017 & 0,000085 & 1,334 & 0,002087 & 0,388 & 0,194 \\
$\mathbf{5 .}$ & 42,5 & 0,017 & 0,000098 & 1,532 & 0,002751 & 0,445 & 0,223 \\
6. & 51 & 0,017 & 0,000111 & 1,741 & 0,003553 & 0,506 & 0,253 \\
\hline
\end{tabular}

Tabel 8. Nilai Crack Growth Rate dan Fatigue Cycle pada Kondisi Terbang 15000 Feet di Setiap Panjang Retakan Simulasi

\begin{tabular}{ccccc}
\hline No. & Panjang Retakan $(\mathrm{mm})$ & $\frac{d a}{d N}(\mathrm{~mm} /$ cycle $)$ & $N_{i}($ cycle $)$ & $N_{f}($ cycle $)$ \\
\hline 1. & 8,5 & $4,947 \times 10^{-14}$ & $1,718 \times 10^{14}$ & $1,718 \times 10^{14}$ \\
2. & 17 & $1,233 \times 10^{-13}$ & $6,892 \times 10^{13}$ & $2,408 \times 10^{14}$ \\
3. & 25,5 & $2,257 \times 10^{-13}$ & $3,766 \times 10^{13}$ & $2,784 \times 10^{14}$ \\
4. & 34 & $3,640 \times 10^{-13}$ & $2,335 \times 10^{13}$ & $3,018 \times 10^{14}$ \\
5. & 42,5 & $5,509 \times 10^{-13}$ & $1,543 \times 10^{13}$ & $3,172 \times 10^{14}$ \\
6. & 51 & $8,087 \times 10^{-13}$ & $1,051 \times 10^{13}$ & $3,277 \times 10^{14}$ \\
\hline
\end{tabular}


Numerical Modeling and Simulation of Fatigue Crack Growth Rate Due To Cyclic Loading on ...

d. Kondisi terbang 20000 feet

Tabel 9. Nilai Cyclic Stress Intensity Factor pada Kondisi Terbang 20000 Feet di Setiap Panjang Retakan Simulasi

\begin{tabular}{cccccccc}
\hline No. & $\mathrm{a}(\mathrm{mm})$ & $\Delta b(\mathrm{~mm})$ & $\Delta u(\mathrm{~mm})$ & $F_{n}(N)$ & $G_{c}\left(\frac{N}{m m}\right)$ & $K(M P a \sqrt{\mathrm{m}})$ & $\Delta K(M P a \sqrt{\mathrm{m}})$ \\
\hline 1. & 8,5 & 0,017 & 0,000054 & 0,850 & 0,000847 & 0,247 & 0,124 \\
2. & 17 & 0,017 & 0,000073 & 1,153 & 0,001557 & 0,335 & 0,167 \\
3. & 25,5 & 0,017 & 0,000090 & 1,410 & 0,002330 & 0,410 & 0,205 \\
4. & 34 & 0,017 & 0,000105 & 1,653 & 0,003204 & 0,480 & 0,240 \\
5. & 42,5 & 0,017 & 0,000121 & 1,899 & 0,004224 & 0,551 & 0,276 \\
6. & 51 & 0,017 & 0,000138 & 2,158 & 0,005456 & 0,627 & 0,313 \\
\hline
\end{tabular}

Tabel 10. Nilai Crack Growth Rate dan Fatigue Cycle pada Kondisi Terbang 20000 Feet di Setiap Panjang Retakan Simulasi

\begin{tabular}{ccccc}
\hline No. & Panjang Retakan $(\mathrm{mm})$ & $\frac{d a}{d N}(\mathrm{~mm} /$ cycle $)$ & $N_{i}($ cycle $)$ & $N_{f}($ cycle $)$ \\
\hline 1. & 8,5 & $9,412 \times 10^{-14}$ & $9,412 \times 10^{-14}$ & $9,031 \times 10^{13}$ \\
2. & 17 & $2,346 \times 10^{-13}$ & $2,346 \times 10^{-13}$ & $1,265 \times 10^{14}$ \\
3. & 25,5 & $4,294 \times 10^{-13}$ & $4,294 \times 10^{-13}$ & $1,463 \times 10^{14}$ \\
4. & 34 & $6,925 \times 10^{-13}$ & $6,925 \times 10^{-13}$ & $1,586 \times 10^{14}$ \\
5. & 42,5 & $1,048 \times 10^{-12}$ & $1,048 \times 10^{-12}$ & $1,667 \times 10^{14}$ \\
6. & 51 & $1,539 \times 10^{-12}$ & $1,539 \times 10^{-12}$ & $1,722 \times 10^{14}$ \\
\hline
\end{tabular}

e. Kondisi terbang 25000 feet

Tabel 11. Nilai Cyclic Stress Intensity Factor pada Kondisi Terbang 25000 Feet di Setiap Panjang Retakan Simulasi

\begin{tabular}{cccccccc}
\hline No. & $\mathrm{a}(\mathrm{mm})$ & $\Delta b(\mathrm{~mm})$ & $\Delta u(\mathrm{~mm})$ & $F_{n}(N)$ & $G_{c}\left(\frac{N}{m m}\right)$ & $K(\operatorname{MPa} \sqrt{\mathrm{m}})$ & $\Delta K(\operatorname{MPa} \sqrt{\mathrm{m}})$ \\
\hline 1. & 8,5 & 0,017 & 0,000064 & 0,999 & 0,001170 & 0,290 & 0,145 \\
2. & 17 & 0,017 & 0,000086 & 1,355 & 0,002152 & 0,394 & 0,197 \\
3. & 25,5 & 0,017 & 0,000106 & 1,658 & 0,003219 & 0,481 & 0,241 \\
4. & 34 & 0,017 & 0,000124 & 1,944 & 0,004427 & 0,565 & 0,282 \\
5. & 42,5 & 0,017 & 0,000142 & 2,232 & 0,005836 & 0,648 & 0,324 \\
6. & 51 & 0,017 & 0,000162 & 2,536 & 0,007538 & 0,737 & 0,368 \\
\hline
\end{tabular}

Tabel 12. Nilai Crack Growth Rate dan Fatigue Cycle pada Kondisi Terbang 25000 Feet di Setiap Panjang Retakan Simulasi

\begin{tabular}{ccccc}
\hline No. & Panjang Retakan $(\mathrm{mm})$ & $\frac{d a}{d N}(\mathrm{~mm} /$ cycle $)$ & $N_{i}($ cycle $)$ & $N_{f}($ cycle $)$ \\
\hline 1. & 8,5 & $1,528 \times 10^{-13}$ & $5,561 \times 10^{13}$ & $5,561 \times 10^{13}$ \\
2. & 17 & $3,811 \times 10^{-13}$ & $2,231 \times 10^{13}$ & $7,792 \times 10^{13}$ \\
3. & 25,5 & $6,973 \times 10^{-13}$ & $1,219 \times 10^{13}$ & $9,011 \times 10^{13}$ \\
4. & 34 & $1,125 \times 10^{-12}$ & $7,558 \times 10^{12}$ & $9,766 \times 10^{13}$ \\
5. & 42,5 & $1,702 \times 10^{-12}$ & $4,993 \times 10^{12}$ & $1,027 \times 10^{14}$ \\
6. & 51 & $2,499 \times 10^{-12}$ & $3,402 \times 10^{12}$ & $1,061 \times 10^{14}$ \\
\hline
\end{tabular}

f. Kondisi terbang 30000 feet

Tabel 13. Nilai Cyclic Stress Intensity Factor pada Kondisi Terbang 30000 Feet di Setiap Panjang Retakan Simulasi

\begin{tabular}{cccccccc}
\hline No. & $\mathrm{a}(\mathrm{mm})$ & $\Delta b(\mathrm{~mm})$ & $\Delta u(\mathrm{~mm})$ & $F_{n}(N)$ & $G_{c}\left(\frac{N}{m m}\right)$ & $K(\operatorname{MPa} \sqrt{\mathrm{m}})$ & $\Delta K(\operatorname{MPa} \sqrt{\mathrm{m}})$ \\
\hline 1. & 8,5 & 0,017 & 0,000071 & 1,118 & 0,001466 & 0,325 & 0,162 \\
2. & 17 & 0,017 & 0,000097 & 1,517 & 0,002696 & 0,441 & 0,220 \\
3. & 25,5 & 0,017 & 0,000118 & 1,855 & 0,004033 & 0,539 & 0,269 \\
4. & 34 & 0,017 & 0,000139 & 2,176 & 0,005547 & 0,632 & 0,316 \\
5. & 42,5 & 0,017 & 0,000159 & 2,498 & 0,007313 & 0,726 & 0,363 \\
6. & 51 & 0,017 & 0,000181 & 2,839 & 0,009445 & 0,825 & 0,412 \\
\hline
\end{tabular}


Tabel 14. Nilai Crack Growth Rate dan Fatigue Cycle pada Kondisi Terbang 30000 Feet di Setiap Panjang Retakan Simulasi

\begin{tabular}{ccccc}
\hline No. & Panjang Retakan $(\mathrm{mm})$ & $\frac{d a}{d N}(\mathrm{~mm} /$ cycle $)$ & $N_{i}($ cycle $)$ & $N_{f}($ cycle $)$ \\
\hline 1. & 8,5 & $2,144 \times 10^{-13}$ & $3,965 \times 10^{13}$ & $3,965 \times 10^{13}$ \\
2. & 17 & $5,345 \times 10^{-13}$ & $1,590 \times 10^{13}$ & $5,555 \times 10^{13}$ \\
3. & 25,5 & $9,781 \times 10^{-13}$ & $8,690 \times 10^{12}$ & $6,424 \times 10^{13}$ \\
4. & 34 & $1,578 \times 10^{-12}$ & $5,388 \times 10^{12}$ & $6,963 \times 10^{13}$ \\
$\mathbf{5 .}$ & 42,5 & $2,388 \times 10^{-12}$ & $3,560 \times 10^{12}$ & $7,319 \times 10^{13}$ \\
6. & 51 & $3,505 \times 10^{-12}$ & $2,425 \times 10^{12}$ & $7,561 \times 10^{13}$ \\
\hline
\end{tabular}

g. Kondisi terbang 35000 feet

Tabel 15. Nilai Cyclic Stress Intensity Factor pada Kondisi Terbang 35000 Feet di Setiap Panjang Retakan Simulasi

\begin{tabular}{cccccccc}
\hline No. & a $(\mathrm{mm})$ & $\Delta b(\mathrm{~mm})$ & $\Delta u(\mathrm{~mm})$ & $F_{n}(N)$ & $G_{c}\left(\frac{N}{m m}\right)$ & $K(\operatorname{MPa} \sqrt{\mathrm{m}})$ & $\Delta K(\operatorname{MPa} \sqrt{\mathrm{m}})$ \\
\hline 1. & 8,5 & 0,017 & 0,000077 & 1,208 & 0,001710 & 0,351 & 0,175 \\
2. & 17 & 0,017 & 0,000104 & 1,638 & 0,003145 & 0,476 & 0,238 \\
3. & 25,5 & 0,017 & 0,000128 & 2,004 & 0,004705 & 0,582 & 0,291 \\
4. & 34 & 0,017 & 0,000150 & 2,350 & 0,006470 & 0,683 & 0,341 \\
5. & 42,5 & 0,017 & 0,000172 & 2,698 & 0,008530 & 0,784 & 0,392 \\
6. & 51 & 0,017 & 0,000195 & 3,066 & 0,011017 & 0,891 & 0,445 \\
\hline
\end{tabular}

Tabel 16. Nilai Crack Growth Rate dan Fatigue Cycle pada Kondisi Terbang 35000 Feet di Setiap Panjang Retakan Simulasi

\begin{tabular}{ccccc}
\hline No. & Panjang Retakan $(\mathrm{mm})$ & $\frac{d a}{d N}(\mathrm{~mm} /$ cycle $)$ & $N_{i}($ cycle $)$ & $N_{f}($ cycle $)$ \\
\hline 1. & 8,5 & $2,701 \times 10^{-13}$ & $3,147 \times 10^{13}$ & $3,147 \times 10^{13}$ \\
2. & 17 & $6,733 \times 10^{-13}$ & $1,262 \times 10^{13}$ & $4,410 \times 10^{13}$ \\
3. & 25,5 & $1,232 \times 10^{-12}$ & $6,898 \times 10^{12}$ & $5,099 \times 10^{13}$ \\
4. & 34 & $1,987 \times 10^{-12}$ & $4,277 \times 10^{12}$ & $5,527 \times 10^{13}$ \\
5. & 42,5 & $3,008 \times 10^{-12}$ & $2,826 \times 10^{12}$ & $5,810 \times 10^{13}$ \\
6. & 51 & $4,415 \times 10^{-12}$ & $1,925 \times 10^{12}$ & $6,002 \times 10^{13}$ \\
\hline
\end{tabular}

h. Kondisi terbang 40000 feet

Tabel 17. Nilai Cyclic Stress Intensity Factor pada Kondisi Terbang 40000 Feet di Setiap Panjang Retakan Simulasi

\begin{tabular}{cccccccc}
\hline No. & $\mathrm{a}(\mathrm{mm})$ & $\Delta b(\mathrm{~mm})$ & $\Delta u(\mathrm{~mm})$ & $F_{n}(N)$ & $G_{c}\left(\frac{N}{m m}\right)$ & $K(M P a \sqrt{\mathrm{m}})$ & $\Delta K(M P a \sqrt{\mathrm{m}})$ \\
\hline 1. & 8,5 & 0,017 & 0,000083 & 1,297 & 0,001973 & 0,377 & 0,188 \\
2. & 17 & 0,017 & 0,000112 & 1,760 & 0,003628 & 0,511 & 0,256 \\
3. & 25,5 & 0,017 & 0,000137 & 2,152 & 0,005427 & 0,625 & 0,313 \\
4. & 34 & 0,017 & 0,000161 & 2,524 & 0,007464 & 0,733 & 0,367 \\
5. & 42,5 & 0,017 & 0,000185 & 2,898 & 0,009840 & 0,842 & 0,421 \\
6. & 51 & 0,017 & 0,000210 & 3,293 & 0,012710 & 0,957 & 0,478 \\
\hline
\end{tabular}

Tabel 18. Nilai Crack Growth Rate dan Fatigue Cycle pada Kondisi Terbang 40000 Feet di Setiap Panjang Retakan Simulasi

\begin{tabular}{ccccc}
\hline No. & Panjang Retakan $(\mathrm{mm})$ & $\frac{d a}{d N}(\mathrm{~mm} /$ cycle $)$ & $N_{i}($ cycle $)$ & $N_{f}($ cycle $)$ \\
\hline $\mathbf{1 .}$ & 8,5 & $3,347 \times 10^{-13}$ & $2,540 \times 10^{13}$ & $2,540 \times 10^{13}$ \\
2. & 17 & $8,343 \times 10^{-13}$ & $1,019 \times 10^{13}$ & $3,559 \times 10^{13}$ \\
3. & 25,5 & $1,527 \times 10^{-12}$ & $5,567 \times 10^{12}$ & $4,115 \times 10^{13}$ \\
4. & 34 & $2,462 \times 10^{-12}$ & $3,452 \times 10^{12}$ & $4,461 \times 10^{13}$ \\
$\mathbf{5 .}$ & 42,5 & $3,727 \times 10^{-12}$ & $2,280 \times 10^{12}$ & $4,689 \times 10^{13}$ \\
6. & 51 & $5,471 \times 10^{-12}$ & $1,554 \times 10^{12}$ & $4,844 \times 10^{13}$ \\
\hline
\end{tabular}

Retakan akan terjadi pada daerah struktur yang memiliki nilai konsentrasi yang tinggi, dan jika nilai konsentrasi tegangan pada daerah tersebut tidak dikurangi, maka retakan akan merambat atau bertambah 
Numerical Modeling and Simulation of Fatigue Crack Growth Rate Due To Cyclic Loading on ...

panjang. Hal ini dapat dibuktikan dengan hasil analisis mekanika retakan yang ditampilkan pada tabel 3 sampai 18 diatas, nilai crack growth rate semakin bertambah besar seiring dengan meningkatnya panjang retakan dan kondisi terbang simulasi. Jika ditinjau pada persamaan matematis (5), dalam kondisi analisis mekanika retakan menggunakan jenis material yang sama, nilai faktor intensitas tegangan siklik berperan sebagai kontributor utama yang memengaruhi nilai crack growth rate, dan nilai faktor intensitas tegangan siklik pada penelitian ini semakin bertambah besar seiring dengan meningkatnya panjang retakan dan kondisi terbang simulasi. Jika ditinjau pada persamaan matematis (4), nilai faktor intensitas tegangan siklik berbanding lurus dengan nilai strain energy release rate, dan berdasarakan persamaan matematis (3), faktorfaktor yang memengaruhi nilai strain energy release rate adalah nilai gaya pada nodal di ujung retakan, crack opening displacement, panjang tepi elemen di dekat ujung retakan, dan tebal material uji. Melalui simulasi pembebanan yang dilakukan melalui software SIMULIA ABAQUS dihasilkan nilai tebal material uji dan panjang tepi elemen di dekat ujung retakan yang kosntan, dan diikuti dengan semakin bertambah besarnya nilai gaya pada nodal di ujung retakan dan crack opening displacement pada setiap panjang retakan dan kondisi terbang simulasi. Melalui hasil tersebut, nilai strain energy release rate semakin bertambah besar sering meningkatnya panjang retakan dan kondisi terbang simulasi.

Berdasarkan hasil analisis mekanika retakan yang dipaparkan sebelumnya, nilai total fatigue cycle struktur doubler semakin meningkat seiring dengan meningkatnya panjang retakan dan semakin berkurang seiring dengan bertambahnya ketinggian terbang pesawat. Nilai total fatigue cycle dipengaruhi secara langsung oleh nilai crack growth rate, hal ini dapat ditinjau melalui persamaan matematis (7).

Seperti yang telah diketahui sebelumnya, bahwa semakin meningkat kondisi terbang maka nilai crack growth rate akan semakin bertambah besar, melalui persamaan matematis (7) tersebut, dapat diketahui bahwa dengan panjang retakan yang konstan tetapi diikuti dengan nilai crack growth rate yang semakin memebesar maka nilai total fatigue cycle akan semakin rendah. Hal ini memberikan hasil bahwa semakin tinggi ketinggian terbang pesawat, maka umur struktur doubler semakin rendah terhadap jumlah siklus pembebanan yang terjadi di ketinggian tersebut.

Untuk pengaruh panjang retakan terhadap nilai total fatigue cycle dapat ditinjau melalui persamaan matematis (8), melalui persamaan matematis tersebut dapat diketahui bahwa nilai total fatigue cycle merupakan hasil penjumlahan dari crack propagation fatigue cycle dengan total fatigue cycle pada panjang retakan sebelumnya. Dengan demikian, hal tersebut menyimpulkan bahwa semakin panjang retakan, maka jumlah siklus pembebanan yang dibutuhkan untuk memunculkan retakan dengan panjang tersebut juga akan semakin banyak.

\section{KESIMPULAN}

Berdasarkan hasil simulasi pembebanan dan analisis mekanika retakan yang telah dilakukan, maka dapat ditarik beberapa kesimpulan. Adapun kesimpulan tersebut adalah sebagai berikut:

a. Nilai crack growth rate yang terjadi pada setiap panjang retakan dan ketinggian terbang simulasi ditampilkan pada bab 3. Melalui nilai tersebut dapat diketahui bahwa nilai crack growth rate berbanding lurus terhadap variasi panjang retakan dan ketinggian terbang simulasi yang diberikan, di mana nilai paling rendah terjadi pada retakan dengan panjang $8,5 \mathrm{~mm}$ dan kondisi terbang 5000 feet yaitu sebesar $2,964 \times 10^{-15} \mathrm{~mm} /$ cycle, dan nilai tertinggi terjadi pada retakan dengan panjang $51 \mathrm{~mm}$ dan kondisi terbang 40000 feet yaitu sebesar 5,471 $\times 10^{-12} \mathrm{~mm} /$ cycle.

b. Nilai fatigue cycle yang terjadi pada setiap panjang retakan dan ketinggian terbang simulasi ditampilkan pada bab 3. Melalui nilai tersebut dapat diketahui bahwa nilai fatigue cycle berbanding lurus terhadap variasi panjang retakan dan ketinggian terbang simulasi yang diberikan, atau semakin meningkat seiring dengan bertambahnya panjang retakan dan semakin berkurang seiring dengan bertambahnya ketinggian terbang pesawat. Nilai fatigue cycle paling rendah terjadi pada retakan dengan panjang $8,5 \mathrm{~mm}$ dan kondisi terbang 40000 feet yaitu sebesar $2,540 \times 10^{13}$ cycle, dan nilai tertinggi terjadi pada retakan dengan panjang $51 \mathrm{~mm}$ dan kondisi terbang 5000 feet yaitu sebesar $5,470 \times 10^{15}$ cycle.

c. Melalui hasil analisis mekanika retakan, dapat diketahui bahwa dengan nilai pembebanan yang konstan ataupun semakin membesar, nilai cyclic stress intensity factor $(\Delta K)$ akan meningkat seiring memanjangnya rambatan retak. Jika kondisi ini terus berlanjut akan mengakibatkan pertumbuhan retak berakselerasi dengan cepat dan menjadi tidak stabil, sehingga nilai maximum stress intensity factor $\left(\mathrm{K}_{\mathrm{max}}\right)$ pada ujung retakan akan sama dengan lebih besar dengan nilai fracture toughness $\left(\mathrm{K}_{\mathrm{Ic}}\right)$ material $\left(K_{\max } \geq K_{I c}\right.$,), dan jika kondisi ini terpenuhi maka struktur doubler akan mengalami fatigue fracture. Namun, selama periode panjang retakan dan nilai pembebanan simulasi yang diberikan, struktur doubler dinyatakan masih dapat menahan terjadinya fatigue fracture karena nilai maximum stress intensity factor paling tinggi terjadi pada panjang retakan $51 \mathrm{~mm}$ dengan kondisi terbang 40000 
feet yaitu sebesar 0,957 MPa $\sqrt{\mathrm{m}}$, dan nilai ini masih di bawah nilai fracture toughness yaitu sebesar $72.37 \mathrm{MPa} \sqrt{\mathrm{m}}$.

\section{UCAPAN TERIMA KASIH}

Terima kasih kami ucapkan kepada seluruh pihak yang telah berkontribusi dalam proses penelitian ini baik secara langsung ataupun tidak langsung, khususnya kepada bapak DR. Muhammad Ridlo Erdata Nasution yang telah menyempatkan untuk meluangkan waktunya di tengah kesibukan beliau sehari-hari demi membantu proses penelitian ini secara keseluruhan.

\section{DAFTAR PUSTAKA}

[1] W. D. Santoso, W. Ari,"Analisis Kekuatan Struktur Retak Skin Fuselage Repair Pesawat B747-400", Seminar Nasional Teknologi Informasi Dan Kedirgantaraan (SENATIK), Vol.2, Nov. 2016.

[2] W. D. Santoso,"Analisis Kekuatan Struktur Repair Skin Doubler Pesawat B737-300”, Angkasa Jurnal Ilmiah Bidang Teknologi, Vol.8. No. 2, Nov. 2016.

[3] Guspriady,"Analisis Kekuatan Struktur Pada Repair Skin Fuselage Pesawat Boeing 737-900 ER Dari STA-847 Sampai STA-867 Menggunakan Software Catia V5R20", Program Studi Teknik Penerbangan Sekolah Tinggi Teknologi Adisutjipto Yogyakarta, 2016.

[4] B. K. Venkatesha, K. P. Prashanth, T. K. Deepak,"Investigation of Fatigue Crack Growth Rate in Fuselage of Large Transport Aircraft using FEA Approach", Global Journal of Researches in Engineering, Mechanical and Mechanics Engineering, Vol. 14, Jan. 2014.

[5] Boeing, "Chapter 53 Fuselage", Chicago: Boeing Structural Repair Manual, 2018.

[6] J. Roesler, H. Harders, and M. Beaker, "Mechanical Behavior of Engineering Materials Metals, Ceramics, Polymers, and Components, Berlin: Springer Science \& Business Media, 2007.

[7] H. N. Firmansyah, "Estimasi Nilai Faktor Intensitas Tegangan (KI) Tipe Center Crack Dengan Metode Numerik", Conference SENATIK STT Adisutjipto Yogyakarta, Vol. 2, Nov. 2016.

[8] H. N. Firmansyah, "Predicting Stress Intensity Factor (KI) Of Single Edge Crack Using Displacement Extrapolation Method", Conference SENATIK STT Adisutjipto Yogyakarta, Vol. 4, Des. 2018.

[9] V. C. Raj, Aldo, Gowrishankar,"Study on the Fatigue Life Estimation of an Airframe Fuselage Window Cutout Panel", International Journal for Research in Applied Science \& Engineering Technology (IJRASET), Vol 6, Mei. 2018.

[10] N. V. Deepashri, M. Kalaiyapan,'Life extension of Structural Repairs - A Statistical Approach Towards Efficiency Improvement", International Conference on Aerospace and Mechanical Engineering (AeroMech17), Vol 370, Mei. 2018.

[11] Kemendikbud,"Maintenance Practice", 2014.

[12] A. B. Selan,"Analisis Damage Tolerance Dan Crack Growth Pada Alumunium 2024-T3 Dan Alumunium 7075T7351 Menggunakan Perangkat Lunak Matlab", Departemen Teknik Dirgantara Sekolah Tinggi Teknologi Adisutjipto, 2018.

[13] D. Roylance,"Introduction to Fracture Mechanics”, Departement of Materials Science and Engineering MIT, Juni. 2001.

[14] M. Milkota, S. Staib, S. Schmauder, Ž. Božić,"Numerical determination of Paris law constants for carbon steel using a two-scale model", 6th International Conference on Fracture Fatigue and Wear, IOP Conf. Series: Journal of Physics: Conf. Series 843, Sep. 2017. 